\title{
Synthesis, Characterization and Crystal Structures of Oxidovanadium(V) Complexes with Schiff Base and Pyrone Ligands and Their Antimicrobial Activity
}

\author{
Guo-Xu He, Ling-Wei Xue*, Qin-Long Peng, Pan-Pan Wang and Hui-Jie Zhang \\ College of Chemistry and Chemical Engineering, Pingdingshan University, Pingdingshan Henan 467000, P.R. China \\ *Corresponding author: E-mail: pdsuchemistry@163.com
}

Received: 11-23-2018

\begin{abstract}
Two oxidovanadium $(\mathrm{V})$ complexes, [VOLL $\left.{ }^{\mathrm{a}}\right](1)$ and $\left[\mathrm{VOLL}^{\mathrm{b}}\right](2)$, where $\mathrm{L}$ is the dianionic form of the Schiff base ligand 2-(((2-hydroxyethyl)imino)methyl)-6-methylphenol $\left(\mathrm{H}_{2} \mathrm{~L}\right), \mathrm{L}^{\mathrm{a}}$ and $\mathrm{L}^{\mathrm{b}}$ are the deprotonated forms of 3-hydroxy2-methyl-4H-pyran-4-one (HL $\left.\mathrm{HL}^{\mathrm{a}}\right)$ and 2-ethyl-3-hydroxy-4H-pyran-4-one $\left(\mathrm{HL}^{\mathrm{b}}\right)$, respectively, have been prepared and characterized by elemental analyses, IR, UV-Vis, ${ }^{1} \mathrm{H}$ NMR and single-crystal X-ray crystallographic determination. The $\mathrm{V}$ atoms in the complexes are in octahedral coordination, with the Schiff base ligand mer-coordinated to the metal atoms through the phenolate $\mathrm{O}$, imino $\mathrm{N}$ and hydroxyl $\mathrm{O}$ atoms, and with the pyrone ligands coordinated to the metal atoms through the two $\mathrm{O}$ atoms. The effect of the compounds on the antimicrobial activity against Staphylococcus aureus, Escherichia coli, and Candida albicans was studied.
\end{abstract}

Keywords: Schiff base; pyrone; vanadium complex; crystal structure; antimicrobial activity

\section{Introduction}

Schiff bases with typical imine group, $\mathrm{C}=\mathrm{N}$, are interesting ligands in coordination chemistry. ${ }^{1}$ In recent years, metal complexes of Schiff bases have attracted remarkable attention due to their versatile biological activity, such as antifungal, antibacterial and antitumor. ${ }^{2}$ Schiff base complexes derived from salicylaldehyde and its derivatives with primary amines, bearing the NNO, NNS, NOO or NSO donor sets, have particular biological activities. ${ }^{3}$ Pyrone compounds are bidentate ligands in various metal complexes. ${ }^{4}$ Most complexes with pyrone ligands have interesting biological properties. ${ }^{5}$ In the present work, two oxidovanadi$\mathrm{um}(\mathrm{V})$ complexes, [VOLL ${ }^{\mathrm{a}}$ ( (1) and [VOLL ${ }^{\mathrm{b}}$ ] (2), where $\mathrm{L}$ is the dianionic form of the Schiff base ligand 2-(((2-hydroxyethyl)imino)methyl)-6-methylphenol $\left(\mathrm{H}_{2} \mathrm{~L}\right), \mathrm{L}^{\mathrm{a}}$ and $\mathrm{L}^{\mathrm{b}}$ are the deprotonated form of 3-hydroxy-2-methyl-4Hpyran-4-one (HL ${ }^{\text {a }}$; maltol) and 2-ethyl-3-hydroxy- $4 \mathrm{H}$ pyran-4-one ( $\mathrm{HL}^{\mathrm{b}}$; ethyl maltol), respectively, are reported.

\section{Experimental}

\section{1. Material and Methods}

3-Methylsalicylaldehyde, 2-aminoethanol, 3-hydroxy-2-methyl-4H-pyran-4-one and 2-ethyl-3-hydroxy-
4H-pyran-4-one were purchased from Fluka. Other reagents and solvents were analytical grade and used without further purification. Elemental $(\mathrm{C}, \mathrm{H}$, and $\mathrm{N}$ ) analyses were made on a Perkin-Elmer Model 240B automatic analyser. Infrared (IR) spectra were recorded on an IR-408 Shimadzu 568 spectrophotometer. UV-Vis spectra were recorded on a Lambda 35 spectrometer. ${ }^{1} \mathrm{H}$ NMR spectra were recorded on a Bruker $300 \mathrm{MHz}$ instrument. X-ray diffraction was carried out on a Bruker SMART 1000 CCD area diffractometer.

\section{2. Synthesis of Complex 1}

3-Methylsalicylaldehyde (13.6 mg, $0.1 \mathrm{mmol}$ ) was dissolved in methanol $(10 \mathrm{~mL})$, to which was added dropwise a methanol solution $(10 \mathrm{~mL})$ containing 2 -aminoethanol $(6.1 \mathrm{mg}, 0.1 \mathrm{mmol})$. The mixture was stirred at ambient temperature for $1 \mathrm{~h}$. Then, 3-hydroxy-2-methyl-4Hpyran-4-one (12.6 mg, $0.1 \mathrm{mmol})$ and $\mathrm{VO}(\mathrm{acac})_{2}(26.5 \mathrm{mg}$, $0.1 \mathrm{mmol})$ dissolved in methanol $(10 \mathrm{~mL})$ was added. The mixture was stirred for $1 \mathrm{~h}$ at ambient temperature to give a deep brown solution. Brown block-shaped single crystals suitable for X-ray diffraction were formed by slow evaporation of the solution in air for several days. The yield is $32 \%$ (based on V). IR data $\left(\mathrm{KBr}, \mathrm{cm}^{-1}\right): 1628(\mathrm{C}=\mathrm{O}), 1597$ 
$(\mathrm{C}=\mathrm{N}), 958(\mathrm{~V}=\mathrm{O}) . \mathrm{UV}-\mathrm{Vis}$ data in methanol $\left[\lambda_{\max }(\mathrm{nm})\right.$, $\left.\varepsilon\left(\mathrm{L} \cdot \mathrm{mol}^{-1} \cdot \mathrm{cm}^{-1}\right)\right]: 218,14,352 ; 280,7,765 ; 407,2,230$. Anal. Calcd. (\%) for $\mathrm{C}_{16} \mathrm{H}_{16} \mathrm{NO}_{6} \mathrm{~V}$ : C, $52.0 ; \mathrm{H}, 4.4 ; \mathrm{N}, 3.8$. Found (\%): C, 52.2; H, 4.3; N, 3.9. ${ }^{1} \mathrm{H}$ NMR (300 MHz, $d^{6}$-DMSO) $\delta$, ppm: $8.94(\mathrm{~s}, 1 \mathrm{H}, \mathrm{CH}=\mathrm{N}), 8.20(\mathrm{~d}, 1 \mathrm{H}, \operatorname{Ar} H)$, 7.43 (d, 1H, ArH), 7.36 (d, 1H, ArH), 6.80 (t, 1H, ArH), $6.41(\mathrm{~d}, 1 \mathrm{H}, \mathrm{ArH}), 4.80\left(\mathrm{~d}, 1 \mathrm{H}, \mathrm{CH}_{2}\right), 4.70\left(\mathrm{t}, 2 \mathrm{H}, \mathrm{CH}_{2}\right)$, $4.40\left(\mathrm{t}, 1 \mathrm{H}, \mathrm{CH}_{2}\right), 2.46\left(\mathrm{~s}, 3 \mathrm{H}, \mathrm{CH}_{3}\right), 1.99\left(\mathrm{~s}, 3 \mathrm{H}, \mathrm{CH}_{3}\right)$.

\section{3. Synthesis of Complex 2}

Complex 2 was prepared by the same method as described for complex 1, with 3-hydroxy-2-methyl-4Hpyran-4-one replaced by 3-hydroxy-2-ethyl-4H-pyran-4one $(14.0 \mathrm{mg}, 0.1 \mathrm{mmol}$ ). The yield is $37 \%$ (based on $\mathrm{V}$ ). IR data $\left(\mathrm{KBr}, \mathrm{cm}^{-1}\right): 1626(\mathrm{C}=\mathrm{O}), 1596(\mathrm{C}=\mathrm{N}), 961(\mathrm{~V}=\mathrm{O})$. $\mathrm{UV}-\mathrm{Vis}$ data in methanol $\left[\lambda_{\max }(\mathrm{nm}), \varepsilon\left(\mathrm{L} \cdot \mathrm{mol}^{-1} \cdot \mathrm{cm}^{-1}\right)\right]$ : $220,15,120 ; 280,8,210 ; 409,2,545$. Anal. Calcd. (\%) for $\mathrm{C}_{17} \mathrm{H}_{18} \mathrm{NO}_{6} \mathrm{~V}$ : C, 53.3; H, 4.7; N, 3.7. Found (\%): C, 53.2; $\mathrm{H}, 4.9 ; \mathrm{N}, 3.5 .{ }^{1} \mathrm{H}$ NMR (300 MHz, $\left.d^{6}-\mathrm{DMSO}\right) \delta$, ppm: $8.94(\mathrm{~s}, 1 \mathrm{H}, \mathrm{CH}=\mathrm{N}), 8.23(\mathrm{~d}, 1 \mathrm{H}, \operatorname{Ar} H), 7.43(\mathrm{~d}, 1 \mathrm{H}, \operatorname{Ar} H)$, 7.36 (d, 1H, ArH), 6.80 (t, 1H, ArH), 6.41 (d, 1H, ArH), $4.80\left(\mathrm{~d}, 1 \mathrm{H}, \mathrm{CH}_{2}\right), 4.72\left(\mathrm{t}, 2 \mathrm{H}, \mathrm{CH}_{2}\right), 4.35\left(\mathrm{t}, 1 \mathrm{H}, \mathrm{CH}_{2}\right), 2.85$ $\left(\mathrm{m}, 2 \mathrm{H}, \mathrm{CH}_{2}\right), 1.98\left(\mathrm{~s}, 3 \mathrm{H}, \mathrm{CH}_{3}\right), 1.23\left(\mathrm{t}, 3 \mathrm{H}, \mathrm{CH}_{3}\right)$.

\section{4. X-Ray Structure Determination}

Data were collected from selected crystals mounted on glass fibres. The data for the two complexes were processed with SAINT ${ }^{6}$ and corrected for absorption using SADABS. ${ }^{7}$ Multi-scan absorption corrections were applied with $\psi$-scans. ${ }^{8}$ The structures were solved by direct methods using the program SHELXS-97 and were refined by full-matrix least-squares techniques on $F^{2}$ using anisotropic displacement parameters. ${ }^{9}$ The structures were refined by SHELXL-97 program. ${ }^{10}$ All hydrogen atoms were placed at the calculated positions. Idealized $\mathrm{H}$ atoms were refined with isotropic displacement parameters set to 1.2 (1.5 for methyl groups) times the equivalent isotropic $U$ values of the parent atoms. The crystallographic data for the complexes are listed in Table 1, selected bond lengths and bond angles for compounds 1 and 2 are given in Table 2.

\section{5. Antimicrobial Assay}

Qualitative determination of antimicrobial activity was done using the disk diffusion method as described in the literature. ${ }^{11}$ Suspensions in sterile peptone water from 24 -h cultures of microorganisms were adjusted to $0.5 \mathrm{Mc}-$

Table 1. Crystallographic data and refinement parameters for complexes 1 and 2

\begin{tabular}{|c|c|c|}
\hline Parameters & 1 & 2 \\
\hline Habit, color & Block, brown & Block, brown \\
\hline Molecular formula & $\mathrm{C}_{16} \mathrm{H}_{16} \mathrm{NO}_{6} \mathrm{~V}$ & $\mathrm{C}_{17} \mathrm{H}_{18} \mathrm{NO}_{6} \mathrm{~V}$ \\
\hline Formula weight & 369.24 & 383.26 \\
\hline Temperature, $\mathrm{K}$ & $298(2)$ & $298(2)$ \\
\hline Crystal size, $\mathrm{mm}$ & $0.31 \times 0.27 \times 0.26$ & $0.32 \times 0.30 \times 0.30$ \\
\hline Radiation $(\lambda, \AA)$ & $\operatorname{MoK}_{\alpha}(0.71073)$ & $\operatorname{MoK}_{\alpha}(0.71073)$ \\
\hline Crystal system & Triclinic & Monoclinic \\
\hline Space group & $P^{-} 1$ & $P 2_{1} / c$ \\
\hline \multicolumn{3}{|l|}{ Unit cell dimensions: } \\
\hline$a, \AA$ & $7.654(2)$ & $7.5888(7)$ \\
\hline$b, \AA$ & $14.692(3)$ & $25.1559(13)$ \\
\hline$c, \AA$ & $14.692(3)$ & $9.5310(9)$ \\
\hline$\alpha,{ }^{\circ}$ & $89.640(3)$ & 90 \\
\hline$\beta$, o & $81.053(3)$ & $107.309(1)$ \\
\hline$\gamma,{ }^{\circ}$ & $81.053(3)$ & 90 \\
\hline$V, \AA^{3}$ & $1611.9(6)$ & $1737.1(2)$ \\
\hline$Z$ & 4 & 4 \\
\hline$\rho_{\text {calcd }}, \mathrm{g} \mathrm{cm}^{-3}$ & 1.521 & 1.465 \\
\hline$F(000)$ & 760 & 792 \\
\hline Absorption coefficient, $\mathrm{mm}^{-1}$ & 0.647 & 0.604 \\
\hline$\theta$ Range for data collection, deg & $1.97-25.50$ & $2.76-25.49$ \\
\hline Index ranges, $h, k, l$ & $-9 \leq h \leq 9 ;-17 \leq k \leq 10 ;-17 \leq l \leq 14$ & $-9 \leq h \leq 9 ;-30 \leq k \leq 30 ;-11 \leq l \leq 11$ \\
\hline Reflections collected & 3971 & 12701 \\
\hline Independent reflections & 2606 & 3139 \\
\hline Data/parameters & $2083 / 437$ & $2625 / 228$ \\
\hline Restraints & 0 & 0 \\
\hline Final $R$ indices $(I>2 \sigma(I))$ & $R_{1}=0.0419, w R_{2}=0.1029$ & $R_{1}=0.0660, w R_{2}=0.1321$ \\
\hline$R$ indices (all data) & $R_{1}=0.0519, w R_{2}=0.1084$ & $R_{1}=0.0802, w R_{2}=0.1371$ \\
\hline Goodness-of-fit on $F^{2}$ & 0.967 & 1.200 \\
\hline
\end{tabular}


Table 2. Selected bond lengths $(\AA)$ and bond angles $\left(^{\circ}\right)$ for complexes 1 and 2

\begin{tabular}{|c|c|c|c|}
\hline \multicolumn{4}{|c|}{1} \\
\hline V1-O1 & $1.890(3)$ & $\mathrm{V} 1-\mathrm{O} 2$ & $1.829(3)$ \\
\hline $\mathrm{V} 1-\mathrm{O} 3$ & $2.292(3)$ & $\mathrm{V} 1-\mathrm{O} 4$ & $1.920(3)$ \\
\hline V1-O6 & $1.606(3)$ & $\mathrm{V} 1-\mathrm{N} 1$ & $2.140(4)$ \\
\hline V2-O7 & $1.880(3)$ & $\mathrm{V} 2-\mathrm{O} 8$ & $1.835(3)$ \\
\hline V2-O9 & $2.279(3)$ & $\mathrm{V} 2-\mathrm{O} 10$ & $1.917(3)$ \\
\hline V2-O12 & $1.597(3)$ & $\mathrm{V} 2-\mathrm{N} 2$ & $2.130(4)$ \\
\hline O6-V1-O2 & $98.52(17)$ & O6-V1-O1 & $96.53(16)$ \\
\hline $\mathrm{O} 2-\mathrm{V} 1-\mathrm{O} 1$ & $157.72(14)$ & O6-V1-O4 & $94.97(15)$ \\
\hline $\mathrm{O} 2-\mathrm{V} 1-\mathrm{O} 4$ & $95.55(14)$ & $\mathrm{O} 1-\mathrm{V} 1-\mathrm{O} 4$ & $99.41(14)$ \\
\hline O6-V1-N1 & $108.63(16)$ & $\mathrm{O} 2-\mathrm{V} 1-\mathrm{N} 1$ & $77.73(13)$ \\
\hline $\mathrm{O} 1-\mathrm{V} 1-\mathrm{N} 1$ & $81.96(13)$ & $\mathrm{O} 4-\mathrm{V} 1-\mathrm{N} 1$ & $156.10(13)$ \\
\hline O6-V1-O3 & $171.28(16)$ & $\mathrm{O} 2-\mathrm{V} 1-\mathrm{O} 3$ & $85.00(14)$ \\
\hline $\mathrm{O} 1-\mathrm{V} 1-\mathrm{O} 3$ & $82.51(14)$ & $\mathrm{O} 4-\mathrm{V} 1-\mathrm{O} 3$ & $76.69(11)$ \\
\hline $\mathrm{N} 1-\mathrm{V} 1-\mathrm{O} 3$ & $79.87(12)$ & $\mathrm{O} 12-\mathrm{V} 2-\mathrm{O} 8$ & $99.40(17)$ \\
\hline O12-V2-O7 & $95.71(16)$ & O8-V2-O7 & $157.75(15)$ \\
\hline $\mathrm{O} 12-\mathrm{V} 2-\mathrm{O} 10$ & $95.74(16)$ & $\mathrm{O} 8-\mathrm{V} 2-\mathrm{O} 10$ & $95.36(15)$ \\
\hline $\mathrm{O} 7-\mathrm{V} 2-\mathrm{O} 10$ & $99.30(13)$ & $\mathrm{O} 12-\mathrm{V} 2-\mathrm{N} 2$ & $106.87(17)$ \\
\hline O8-V2-N2 & $77.60(15)$ & O7-V2-N2 & $82.44(13)$ \\
\hline $\mathrm{O} 10-\mathrm{V} 2-\mathrm{N} 2$ & $157.08(15)$ & O12-V2-O9 & $171.99(15)$ \\
\hline $\mathrm{O} 8-\mathrm{V} 2-\mathrm{O} 9$ & $84.90(15)$ & O7-V2-O9 & $82.19(14)$ \\
\hline O10-V2-O9 & $77.05(11)$ & N2-V2-O9 & $80.58(13)$ \\
\hline \multicolumn{4}{|c|}{2} \\
\hline $\mathrm{V} 1-\mathrm{O} 1$ & $1.867(3)$ & $\mathrm{V} 1-\mathrm{O} 2$ & $1.838(3)$ \\
\hline $\mathrm{V} 1-\mathrm{O} 3$ & $1.909(3)$ & $\mathrm{V} 1-\mathrm{O} 4$ & $2.303(3)$ \\
\hline V1-O6 & $1.591(3)$ & $\mathrm{V} 1-\mathrm{N} 1$ & $2.120(4)$ \\
\hline O6-V1-O2 & $97.60(17)$ & O6-V1-O1 & $97.82(16)$ \\
\hline $\mathrm{O} 2-\mathrm{V} 1-\mathrm{O} 1$ & $157.86(14)$ & O6-V1-O3 & $95.40(15)$ \\
\hline $\mathrm{O} 2-\mathrm{V} 1-\mathrm{O} 3$ & $98.51(14)$ & $\mathrm{O} 1-\mathrm{V} 1-\mathrm{O} 3$ & $95.75(14)$ \\
\hline O6-V1-N1 & $107.45(16)$ & $\mathrm{O} 2-\mathrm{V} 1-\mathrm{N} 1$ & $77.86(14)$ \\
\hline $\mathrm{O} 1-\mathrm{V} 1-\mathrm{N} 1$ & $82.42(14)$ & $\mathrm{O} 3-\mathrm{V} 1-\mathrm{N} 1$ & $157.13(13)$ \\
\hline O6-V1-O4 & $172.29(14)$ & $\mathrm{O} 2-\mathrm{V} 1-\mathrm{O} 4$ & $83.49(14)$ \\
\hline $\mathrm{O} 1-\mathrm{V} 1-\mathrm{O} 4$ & $83.36(14)$ & $\mathrm{O} 3-\mathrm{V} 1-\mathrm{O} 4$ & $76.89(11)$ \\
\hline $\mathrm{N} 1-\mathrm{V} 1-\mathrm{O} 4$ & $80.26(12)$ & & \\
\hline
\end{tabular}

Farland. Muller-Hinton Petri dishes of $90 \mathrm{~mm}$ were inoculated using these suspensions. Paper disks $(6 \mathrm{~mm}$ in diameter) containing $10 \mu \mathrm{L}$ of the substance to be tested (at a concentration of $2048 \mu \mathrm{g} / \mathrm{mL}$ in DMSO) were placed in a circular pattern in each inoculated plate. Incubation of the plates was done at $37^{\circ} \mathrm{C}$ for $18-24 \mathrm{~h}$. Reading of the results was done by measuring the diameters of the inhibition zones generated by the test substance. Tetracycline was used as a reference substance. Determination of MIC was done using the serial dilutions in liquid broth method. The materials used were 96-well plates, suspensions of microorganism (0.5 McFarland), Muller-Hinton broth (Merck) and stock solutions of each substance to be tested (2048 $\mu \mathrm{g} / \mathrm{mL}$ in DMSO). The following concentrations of the substances to be tested were obtained in the 96-well plates: $1024,512,256,128,64,32,16,8,4$ and $2 \mu \mathrm{g} / \mathrm{mL}$. After incubation at $37^{\circ} \mathrm{C}$ for $18-24 \mathrm{~h}$, the MIC for each tested substance was determined by microscopic observation of microbial growth. It corresponds to the well with the lowest concentration of the tested substance where microbial growth was clearly inhibited.

\section{Results and Discussion}

\subsection{Chemistry}

The Schiff base compound $\mathrm{H}_{2} \mathrm{~L}$ was prepared by the condensation of equimolar quantities of 3-methylsalicylaldehyde with 2 -aminoethanol in methanol. Complexes 1 and 2 were readily synthesized by reaction of the Schiff base compound $\mathrm{H}_{2} \mathrm{~L}$ with $\mathrm{VO}(\mathrm{acac})_{2}$ in methanol in the presence of 3-hydroxy-2-methyl-4H-pyran-4-one and 2-ethyl-3-hydroxy-4H-pyran-4-one, respectively (Scheme 1). All the compounds are very stable at room temperature in the solid state, and soluble in common organic solvents, such as methanol, ethanol, and acetonitrile. The results of

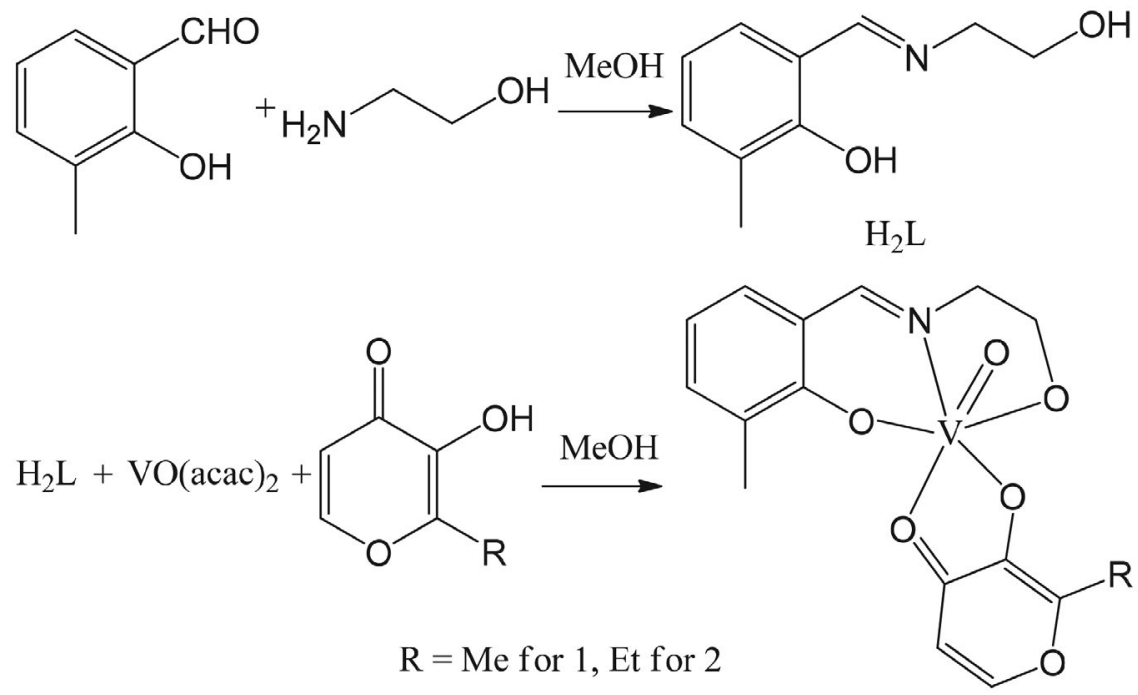

Scheme 1. The synthetic procedure of the complexes. 
the elemental analyses are in accord with the composition suggested for the Schiff base and the complexes.

\section{2. IR and UV-Vis Spectra}

For the IR spectrum of $\mathrm{H}_{2} \mathrm{~L}$ (Fig. S1), the typical band indicative of the azomethine group was observed at $1622 \mathrm{~cm}^{-1}$, while in the complexes (Figs. S2 and S3), it was observed at $1597 \mathrm{~cm}^{-1}$ for 1 and $1596 \mathrm{~cm}^{-1}$ for 2 . The strong absorptions at $1626-1628 \mathrm{~cm}^{-1}$ in the spectra of the complexes are assigned to the stretching vibration of the $\mathrm{C}=\mathrm{O}$ bonds of the pyrone ligands. The weak absorption at 3439 $\mathrm{cm}^{-1}$ for $\mathrm{H}_{2} \mathrm{~L}$ can be attributed to the vibration of $\mathrm{O}-\mathrm{H}$ groups, while in the complexes, there are no such absorption. The absence of this absorption indicates the coordination of the hydroxyl groups in the deprotonated form. The bands indicative of the $\mathrm{V}=\mathrm{O}$ groups of the complexes are observed at about $960 \mathrm{~cm}^{-1}$. UV-Vis spectra of $\mathrm{H}_{2} \mathrm{~L}$ and the complexes were measured in methanol. In the spectrum of the Schiff base (Fig. S4), the band centered at $325 \mathrm{~nm}$ is attributed to the azomethine chromophore $\pi-\pi^{*}$ transition. The band at higher energy $(272 \mathrm{~nm})$ is associated with the benzene $\pi-\pi^{*}$ transition. In the spectra of the complexes (Figs. S5 and S6), the bands at 407-409 nm are attributed to the intramolecular charge transfer transitions from the $p_{\pi}$ orbital on the phenolate $\mathrm{O}$ to the empty $d$ orbitals of the $\mathrm{V}$ atoms. ${ }^{12}$

\section{3. Structure Description of the Complexes}

The molecular structures of complexes 1 and 2 are shown in Figs. 1 and 2, respectively. There are two independent molecules in complex 1 . The $\mathrm{V}$ atoms are mer-coordinated by one Schiff base ligand, one pyrone ligand, and one oxo $\mathrm{O}$ group. The Schiff base ligand coordinated to the $\mathrm{V}$ atom through the phenolate $\mathrm{O}$, imino $\mathrm{N}$, and deprotonated hydroxyl $\mathrm{O}$ atoms. The pyrone ligands are coordinated to the $\mathrm{V}$ atoms through the deprotonated hydroxyl $\mathrm{O}$ and carbonyl $\mathrm{O}$ atoms. The $\mathrm{V}$ atoms are in octahedral coordination, with the three donor atoms of the Schiff base ligand, and the hydroxyl $\mathrm{O}$ atom of the pyrone ligand defining the equatorial plane, and with the carbonyl $\mathrm{O}$ atom of the pyrone ligand, and the oxo $\mathrm{O}$ group occupying the axial positions. In the two complexes, the corresponding bond distances around the $\mathrm{V}$ atoms are comparable to each other, and also similar to the corresponding bonds observed in the similar vanadium complexes with Schiff bases or pyrones. ${ }^{13}$ The cis and trans coordinate bond angles in the equatorial planes are range from $77.73(13)$ to $99.41(14)^{\circ}$ and from $156.10(13)$ to $157.72(14)^{\circ}$ for the $\mathrm{V} 1$ atom of complex 1 , from $77.60(15)$ to $99.30(13)^{\circ}$ and from $157.08(15)$ to $157.75(15)^{\circ}$ for the V2 atom of complex 1, and from $77.86(14)$ to $98.51(14)^{\circ}$ and from $157.13(13)$ to $157.86(14)^{\circ}$ for the $\mathrm{V}$ atom of complex 2, respectively. In addition, the values for the axial trans $\mathrm{O}-\mathrm{V}-\mathrm{O}$ angles are $171.28(16)^{\circ}$ and $171.99(15)^{\circ}$, respec-

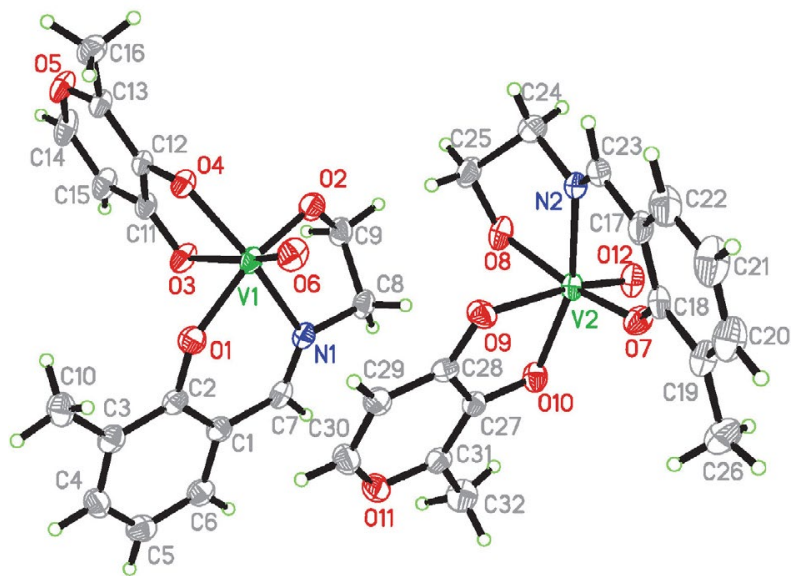

Fig. 1. Perspective view of complex 1 with $30 \%$ probability thermal ellipsoids.

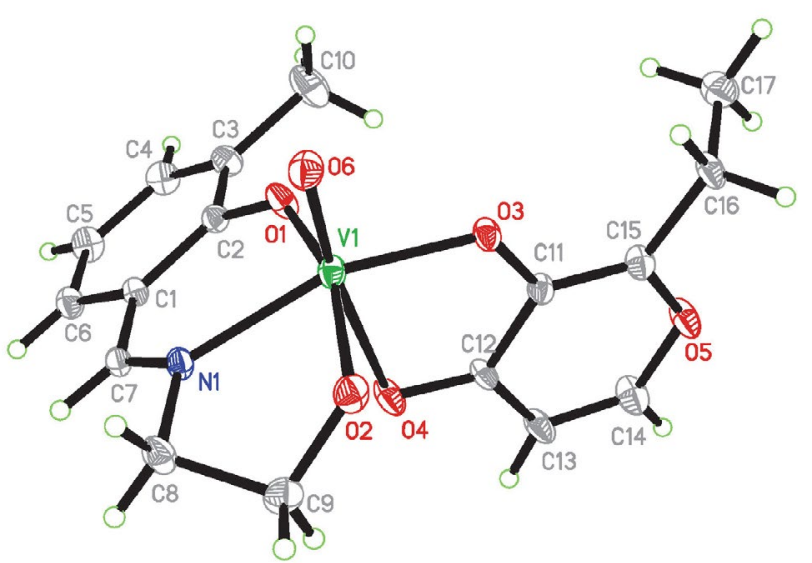

Fig. 2. Perspective view of complex 2 with $30 \%$ probability thermal ellipsoids.

tively, for the V1 and V2 atoms of complex 1, and $172.29(14)^{\circ}$ for the $\mathrm{V}$ atom of complex 2. All the above bond values indicating the distortion of the octahedral coordination from ideal geometry.

\section{4. Antimicrobial Activity}

The antimicrobial activity results are summarized in Table 3. A comparative study of minimum inhibitory concentration (MIC) values of the Schiff base and the complexes indicates that the complexes have better activity than the free Schiff base. Generally, this is caused by the greater lipophilic nature of the complexes than the ligand. Such increased activity of the metal chelates can be explained on the basis of chelating theory. ${ }^{14}$ On chelating, the polarity of the metal atoms will be reduced to a greater extent due to the overlap of the ligand orbital and partial sharing of positive charge of the metal atoms with donor atoms. Further, it increases the delocalization of $p$-electrons over the whole chelate ring and enhances the lipophilicity of the complexes. This increased lipophilicity en- 
Table 3. MIC values $(\mu \mathrm{g} / \mathrm{mL})$ for the antimicrobial activities of the tested compounds

\begin{tabular}{lccc}
\hline Compounds & Staphylococcus aureus & Escherichia coli & Candida albicans \\
\hline $\mathrm{H}_{2} \mathrm{~L}$ & 128 & 64 & $>512$ \\
1 & 4.0 & 1.0 & 32 \\
2 & 4.0 & 1.0 & 32 \\
Tetracycline & 0.32 & 2.12 & $>1024$ \\
\hline
\end{tabular}

hances the penetration of the complexes into lipid membrane and blocks the metal binding sites on enzymes of microorganisms.

From the results, it is obvious that the two complexes have higher antibacterial and antifungal activities against Staphylococcus aureus, Escherichia coli, and Candida albicans when compared to the free Schiff base. This phenomenon is in accordance with those reported in literature. ${ }^{15}$ The two complexes have in general the same activities against all the bacteria and fungi strains. The complexes have strong activity against Escherichia coli, with MIC value of $1.0 \mu \mathrm{g} / \mathrm{mL}$, which is superior to Tetracycline. The complexes have strong activity against Staphylococcus aureus, yet, they are weaker than Tetracycline. It is interesting that both complexes have medium activity against Candida albicans, which is rarely seen in metal complexes.

\section{Mateiral}

CCDC 1880706 for 1 , and 1880707 for 2 contain the supplementary crystallographic data for this paper. These data can be obtained free of charge at http://www.ccdc. cam.ac.uk/const/retrieving.html or from the Cambridge Crystallographic Data Centre, 12 Union Road, Cambridge CB2 1EZ, UK; fax: +44(0)1223-336033 or email: deposit@ ccdc.cam.ac.uk.

\section{Acknowledgments}

This research was supported by the Top-class foundation of Pingdingshan University (no. PXYBSQD-2018006 and PXY-PYJJ-2018002).

\section{References}

1. (a) X. W. Zhu, Russ. J. Coord. Chem. 2018, 44, 421-424; DOI:10.1134/S1070328418070084

(b) D. L. Peng, Russ. J. Coord. Chem. 2017, 43, 189-195; DOI:10.1134/S1070328417030058

(c) D.-L. Peng, J. Struct. Chem. 2018, 59, 589-594;

DOI:10.1134/S0022476618030125

(d) X.-W. Zhu, Acta Chim. Slov. 2018, 65, 939-945.

DOI:10.17344/acsi.2018.4607

2. (a) Z.-C. Liu, B.-D. Wang, Z.-Y. Yang, Y. Li, D.-D. Qin, T.-R.
Li, Eur. J. Med. Chem. 2009, 44, 4477-4484;

DOI:10.1016/j.ejmech.2009.06.009

(b) D.-D. Qin, Z.-Y. Yang, G.-F. Qi, T.-R. Li, Transition Met. Chem. 2009, 34, 499-505;

DOI:10.1007/s11243-009-9222-z

(c) Y.-Y. Yu, H.-D. Xian, J.-F. Liu, G.-L. Zhao, Molecules 2009, 14, 1747-1754. DOI:10.3390/molecules14051747

3. (a) Y.-T. Li, J.-W. Dong, Y. Lu, Y.-T. Gu, C.-N. Shang, F.-Y. Liu, Y. Xin, C.-L. Jing, Z.-L. You, Chinese J. Inorg. Chem. 2018, 34, 1192-1198;

(b) Z. You, H. Yu, Z. Li, W. Zhai, Y. Jiang, A. Li, S. Guo, K. Li, C. Lv, C. Zhang, Inorg. Chim. Acta 2018, 480, 120-126; DOI:10.1016/j.ica.2018.05.020

(c) L. W. Xue, G. Q. Zhao, Y. J. Han, Y. X. Feng, Russ. J. Coord. Chem. 2011, 37, 262-269;

DOI:10.1134/S1070328411030110

(d) Z. You, H. Yu, B. Zheng, C. Zhang, C. Lv, K. Li, L. Pan, Inorg. Chim. Acta 2018, 469, 44-50;

DOI:10.1016/j.ica.2017.09.011

(e) L. W. Xue, Y. J. Han, G. Q. Zhao, Y. X. Feng, Russ. J. Coord. Chem. 2012, 38, 24-28. DOI:10.1134/S1070328411120104

4. (a) B. Song, K. Saatchi, G. H. Rawji, C. Orvig, Inorg. Chim. Acta 2002, 339, 393-399; DOI:10.1016/S0020-1693(02)00961-1

(b) W. Y. Hsieh, S. Liu, Synth. React. Inorg. Met.-Org. Nano-Met. Chem. 2005, 35, 61-70; (c) W. Y. Hsieh, C. M. Zaleski, V. L. Pecoraro, P. E. Fanwick, S. A. Liu, Inorg. Chim. Acta 2006, 359, 228-236; (d) V. Vrdoljak, B. Prugovečki, M. Cindrić, D. Matković-Čalogović, A. Brbot-Šaranović, Acta Chim. Slov. 2008, 55, 828-833;

(e) S. Guo, N. Sun, Y. Ding, A. Li, Y. Jiang, W. Zhai, Z. Li, D. Qu, Z. You, Z. Anorg. Allg. Chem. 2018, 644, 1172-1176.

DOI:10.1002/zaac.201800060

5. (a) M. Rangel, A. Tamura, C. Fukushima, H. Sakurai, J. Biol. Inorg. Chem. 2001, 6, 128-132;

DOI: $10.1007 / \mathrm{s} 007750000180$

(b) C.-T. Yang, S. G. Sreerama, W.-Y. Hsieh, S. Liu, Inorg. Chem. 2008, 47, 2719-2727; DOI:10.1021/ic7022506

(c) D. Sanna, L. Biro, P. Buglyo, G. Micera, E. Garribba, J. Inorg. Biochem. 2012, 115, 87-99;

DOI:10.1016/j.jinorgbio.2012.04.020

(d) E. A. Enyedy, O. Domotor, E. Varga, L. Kiss, R. Trondl, C. G. Hartinger, B. K. Keppler, J. Inorg. Biochem. 2012, 117, 189-197. DOI:10.1016/j.jinorgbio.2012.08.005

6. SMART and SAINT. Area Detector Control and Integration Software, Madison (WI, USA): Bruker Analytical X-ray Instruments Inc., 1997.

7. G. M. Sheldrick, SADABS, Program for Empirical Absorp- 
tion Correction of Area Detector Data, Göttingen (Germany): Univ. of Göttingen, 1997.

8. A. C. T. North, D. C. Phillips, F. S. Mathews, Acta Crystallogr. A 1968, 24, 351-359. DOI:10.1107/S0567739468000707

9. G. M. Sheldrick, SHELXL-97, Program for the Refinement of Crystal Structures, Göttingen (Germany): Univ. of Göttingen, 1997.

10. G. M. Sheldrick, Acta Crystallogr. 2015, C71, 3-8.

11. (a) A. Barry, Procedures and Theoretical Considerations for Testing Antimicrobial Agents in Agar Media, In: Antibiotics in Laboratory Medicine, Lorian, V. (Ed.), Baltimore: Williams and Wilkins, 1991;

(b) T. Rosu, M. Negoiu, S. Pasculescu, E. Pahontu, D. Poirier, A. Gulea, Eur. J. Med. Chem. 2010, 45, 774-781.

DOI:10.1016/j.ejmech.2009.10.034

12. G. Asgedom, A. Sreedhara, J. Kivikoski, E. Kolehmainen, C. P. Rao, J. Chem. Soc. Dalton Trans. 1996, 93-97. DOI:10.1039/dt9960000093

13. (a) D.-L. Peng, Russ. J. Coord. Chem. 2017, 43, 404-410; DOI:10.1134/S1070328417060045

(b) N. Lotfi, I. Sheikhshoaei, S. Y. Ebrahimipour, H. Krautsc- heid, J. Mol. Struct. 2017, 1149, 432-438;

DOI:10.1016/j.molstruc.2017.08.010

(c) H. Y. Qian, Russ. J. Coord. Chem. 2017, 43, 780-786; DOI:10.1134/S1070328417110070

(d) S. K. Mal, M. Mitra, H. R. Yadav, C. S. Purohit, A. R. Choudhury, R. Ghosh, Polyhedron 2016, 111, 118-122; DOI:10.1016/j.poly.2016.03.033

(e) I. Sheikhshoaie, S. Y. Ebrahimipour, N. Lotfi, J. T. Mague, M. Khaleghi, Inorg. Chim. Acta 2016, 442, 151-157;

DOI:10.1016/j.ica.2015.11.026

(f) S. S. Qian, Y. Huo, Y. T. Ye, Z. You, H. L. Zhu, Russ. J. Coord. Chem. 2015, 41, 261-266.

DOI:10.1134/S107032841504003X

14. J. W. Searl, R. C. Smith, S. Wyard, J. Proc. Phys. Soc. 1961, 78, 1174-1181. DOI:10.1088/0370-1328/78/6/311

15. (a) X. W. Zhu, Russ. J. Coord. Chem. 2018, 44, 335-339; DOI:10.3103/S1068367418040213

(b) H. Y. Qian, Russ. J. Coord. Chem. 2018, 44, 32-38;

DOI:10.1134/S1070328418010074

(c) D.-L. Peng, N. Sun, Acta Chim. Slov. 2018, 65, 895-901. DOI:10.17344/acsi.2018.4543

\section{Povzetek}

Sintetizirali smo dve kompleksni spojini oksidovanadija(V), [VOLL $\left.{ }^{\mathrm{a}}\right]$ (1) in [VOLL $\left.{ }^{\mathrm{b}}\right]$ (2), kjer je L dianionska oblika liganda Schiffove baze 2-(((2-hidroksietil) imino) metil)-6-metilfenola $\left(\mathrm{H}_{2} \mathrm{~L}\right), \mathrm{L}^{\mathrm{a}}$ in $\mathrm{L}^{\mathrm{b}}$ sta deprotonirani obliki 3-hidroksi-2-metil-4H-piran-4-ona $\left(\mathrm{HL}^{\mathrm{a}}\right)$ in 2-etil-3-hidroksi-4H-piran-4-ona $\left(\mathrm{HL}^{\mathrm{b}}\right)$. Spojini smo karakterizirali $\mathrm{z}$ naslednjimi metodami: infradrečo spektroskopijo (IR), UV-Vis spektroskopijo, NMR spektroskopijo in rentgensko strukturno analizo monokristalov. Atomi vanadija v spojinah so okatedrično koordinirani $\mathrm{z}$ atomi kisika in dušika, ki pripadajo obema ligandoma. Preučevali smo tudi protimikrobno učinkovitost spojin napram Staphylococcus aureus, Escherichia coli in Candida albicans. 